\title{
CHEVRON-TYPE HALITE AND NODULAR ANHYDRITE IN THE TRIASSIC SUBSURFACE EVAPORITES OF THE IONIAN ZONE (WESTERN GREECE)
}

\author{
Pomoni-Papaioannou F. ${ }^{1}$, Karakitsios V. ${ }^{1}$, Kamberis ${ }^{2}{ }^{2}$ and Marnelis F. ${ }^{2}$ \\ 1 Department of Geology, University of Athens, Panepistimiopolis, 15784 Athens, \\ fpomoni@geol.uoa.gr,vkarak@geol.uoa.gr
}

${ }^{2}$ Hellenic Petroleum, 199, Kifissias Ave.15124 Maroussi, ekamperis@hellenic-petroleum.gr. fmarnelis@hellenic-petroleum.gr

\section{ABSTRACT}

Samples of the Ionian zone (western Greece) subsurface evaporites, obtained from well cores in salt bodies and in depths ranging from 1000 to $3500 \mathrm{~m}$, are texturally studied. Layered halite rocks consisting of chevron-type halite crystals represent most of the specimens. Between the chevron -type halite crystals, which are fluid inclusions-rich, clear halite without inclusions has been diagenetically formed by dissolution and precipitation processes. Anhydrite always accompanies the halite rocks as crystals or nodules. No-occurrence of gypsum has been detected. Along halite grain boundaries dolomite crystals occur. Dolomite grew on halite crystal surfaces as an early diagenetic mineral. Some dolomite crystals are clearly derived by replacement of anhydrite crystals. Halite layers are rich in clay and carbonaceous material favoring reducing environment (presence of pyrite crystals).

Chevron-type halite supports accumulation beneath a body of brine, possibly recording annual precipitation cycles. However, its close association with nodular anhydrite cannot exclude the possibility of halite development, in a shallow-water or emergent environment by displacement from capillary brines. Since the studied halite crystals show evidence of mineral replacements and displacement, we suggest an analogous mechanism including accumulation from a standing body of brine and subsequent textural modification in the groundwater zone.

Although, Ionian subsurface evaporites have undergone the above-mentioned diagenetical processes, they still rete.in their primary textural characteristics. Real brecciation has not been detected in subsurface, except of an in-situ pseudo-brecciation. This observation clearly shows that the outcropping evaporite solution-collapse breccias were formed in the realm of meteoric zone, after the lonian zone orogenesis.

\section{INTRODUCTION}

The distinction between the evaporite sedimentary models, those relating structures and textures to hydrodynamic and other depositional parameters, and the post-depositional models that relate present mineralogical cumposition to the physico-chemical diagenetic processes, is a very difficult task. Of major interest are the early diagenetic changes that affect the sediments, which are controlled by the depositional settings. Concerning the depth of water in which evaporite deposits are formed, it is readily recognizable in the case of small, thin evaporite deposits. In contrast, the environment of formation of vast, thick, basin-central evaporites is not easily discernable. The interpretations of the original sedimentary facies are effectuated by detailed study of the sedimentological and petrographical characteristics based on rock textures and structures. However, it has to be seriously taken under consideration, that the primary sedimentary characteristics are commonly obliterated by variable diagenetical factors and are accentuated by the high solubility of evaporites and their susceptibility to flowage under burial conditions. 
Early to Middle Triassic evaporites constitute the oldest of the known lonian zone (western Greece) formations (Fig. 1 and 3). The "subevaporite beds" of the Ionian zone in western Greece do not crop out, neither are they penetrated by boreholes (IGRS-IFP 1966; BP 1971). These boreholes penetrated in some cases more than $3000 \mathrm{~m}$ of evaporites, proving the great thickness of the evaporitic series. However, the initial thickness of the evaporitic deposits owes to be lesser, because all the boreholes have been drilled in anticline zones, where diapiric phenomena are intense (Karakitsios 1992). Analogous evaporitic series are known in the Paxos (Preapulian) zone (Fig. 1), where the evaporites are located stratigraphically higher into the Liassic limestones (IGRS-IFP, 1966; BP, 1971), in Italy in the Cargano (Carissimo et al. 1963), in the Tuscan-Umbrian domain (Ciarapica et al. 1987) and in former Yugoslavia. These extensive evaporite deposits suggest that a huge evaporitic basin existed in this entire region. Modern sedimentary environments lack examples of such a great evaporitic basin. Actual evaporites are formed in logoons (e.g. sabkhas of north Africa) or deltas. In the Ionian zone, the evaporite deposits have been affected by complex postdepositional modifications and large-scale evaporite dissolution preventing a satisfactory reconstruction of the environment of deposition. The sedimentological study of outcropping evaporitic material suggests formation by lateral and vertical accretion within a depositional environment analogous to those of the present time, in supratidal flats and lagoons (Pomoni-Papaioannou 1983; 1985; Karakitsios \& Pon'oni-Papaioannou 1998).

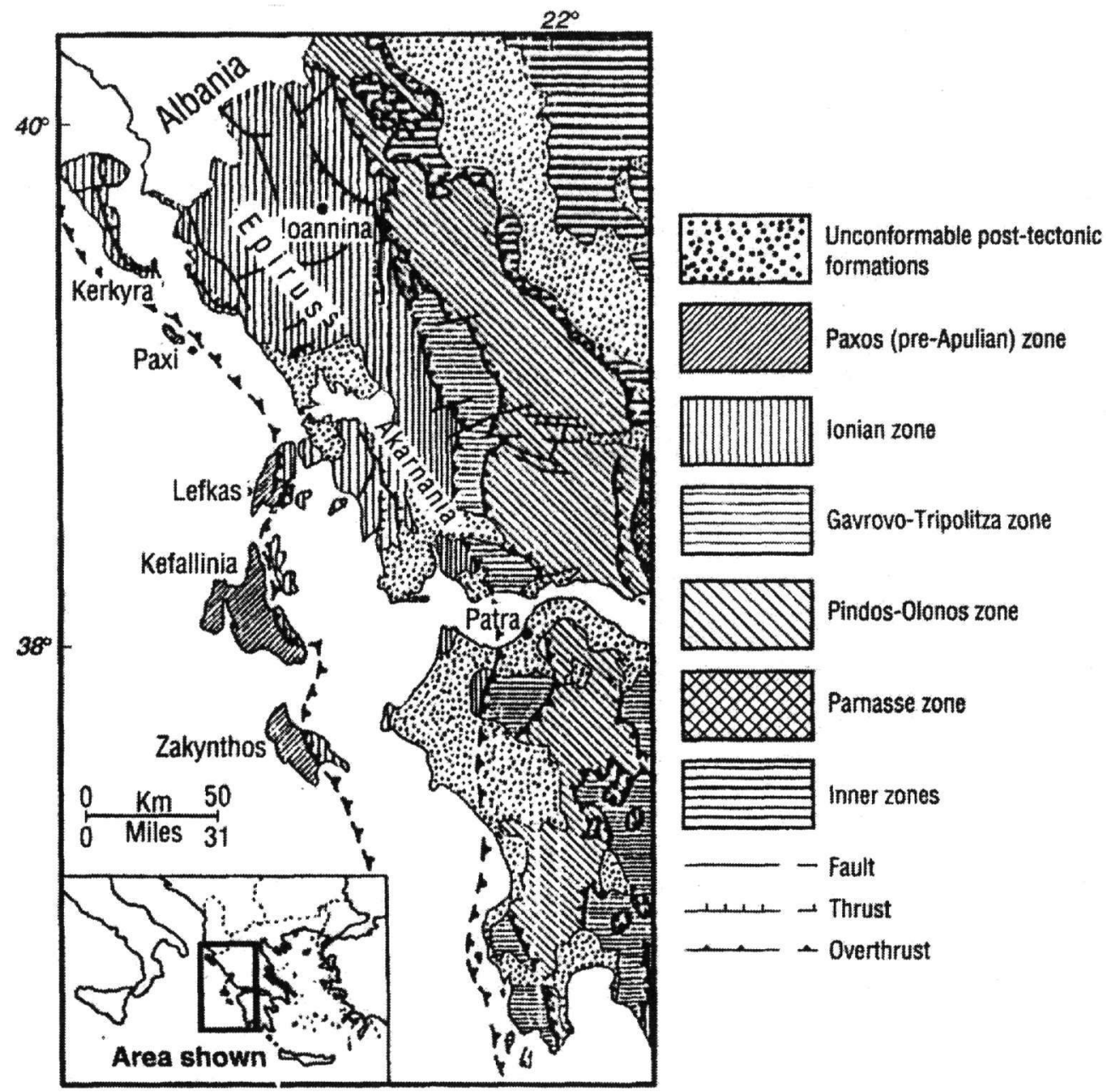

Figure 1. Simplified structural map of western continental Greece (Karakitsios 1995) 
In the present paper, evaporite samples, composed of halite and anhydrite, obtained from well cores and cuttings (Parakalamos-1, Delvinaki-1, Filiates-1 Dimitra-1, Peristeri-1, Katakolo-101, 103, Lasteika-1, Achaia-1, and Myrtia-1 wells, Fig. 2), from depths between 1000 and $3500 \mathrm{~m}$. They were texturally studied and new data arosed, concerning both the origin of the salt bodies of the Ionian zone and the diagenetical processes that were responsible for their present appearance at depth. Emphasis has been given in the study of the brecciation process that gave birth to the socalled "Triassic Breccias Formation", aiming to clarify whether it started already in the realm of the early diagenesis or is the result of a post-depositional mechanism mainly related to post orogenic processes.
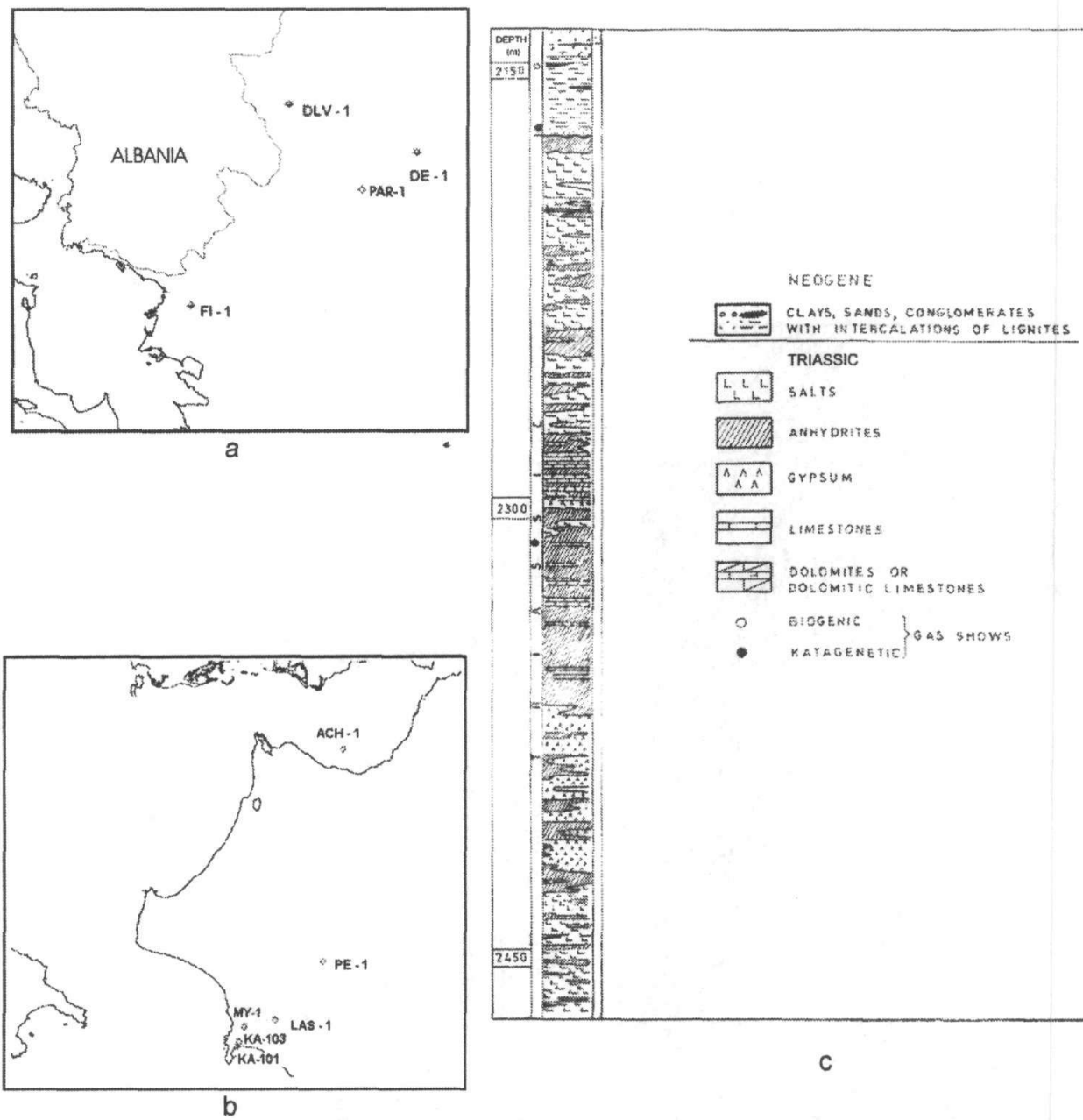

Figure 2. Location of wells in NW Epirus (a) and NW Peloponnesus (b). Indicative lithostratigraphic section (c) of Triassic Evaporites based on Myrtia-1 well (Katakolo region) data.

\section{GEOLOGICAL SETTING}

The stratigraphy of the Ionian zone exhibits three distinct sequences (Fig. 3).

a) A prerift sequence, which is represented by the early Liassic Pantokrator Limestones. These shallow water limestones overlie early to middle Triassic evaporites through Foustapidima Limestones of Ladinian-Rhetian age. 
b) A synrift sequence t. 1at began with the deposition of the Siniais Limestones and their lateral equivalent, the Louros Limestones of Pliensbachian age. These formations correspond to the general sinking of the lonian domain (formation of the Ionian basin), which was followed by an intrabasinal differentiation that separated the initial basin into smaller paleogeographic units presenting, in general, a half-graben geometry. This is recorded in the abruptly changing thickness of the synrift formations, forming prismatic synsedimentary wedges, which, in the deeper part of the halfgrabens, include complete Toarcian to Tithonian successions, while in the elevated part of the halfgrabens hiatuses and unconformities are located. Deposition was controlled both by structures formed during the extensional tectonic phase (related to the opening of the Neotethys Ocean), and the halokinesis of the Ionian zone evaporitic base.

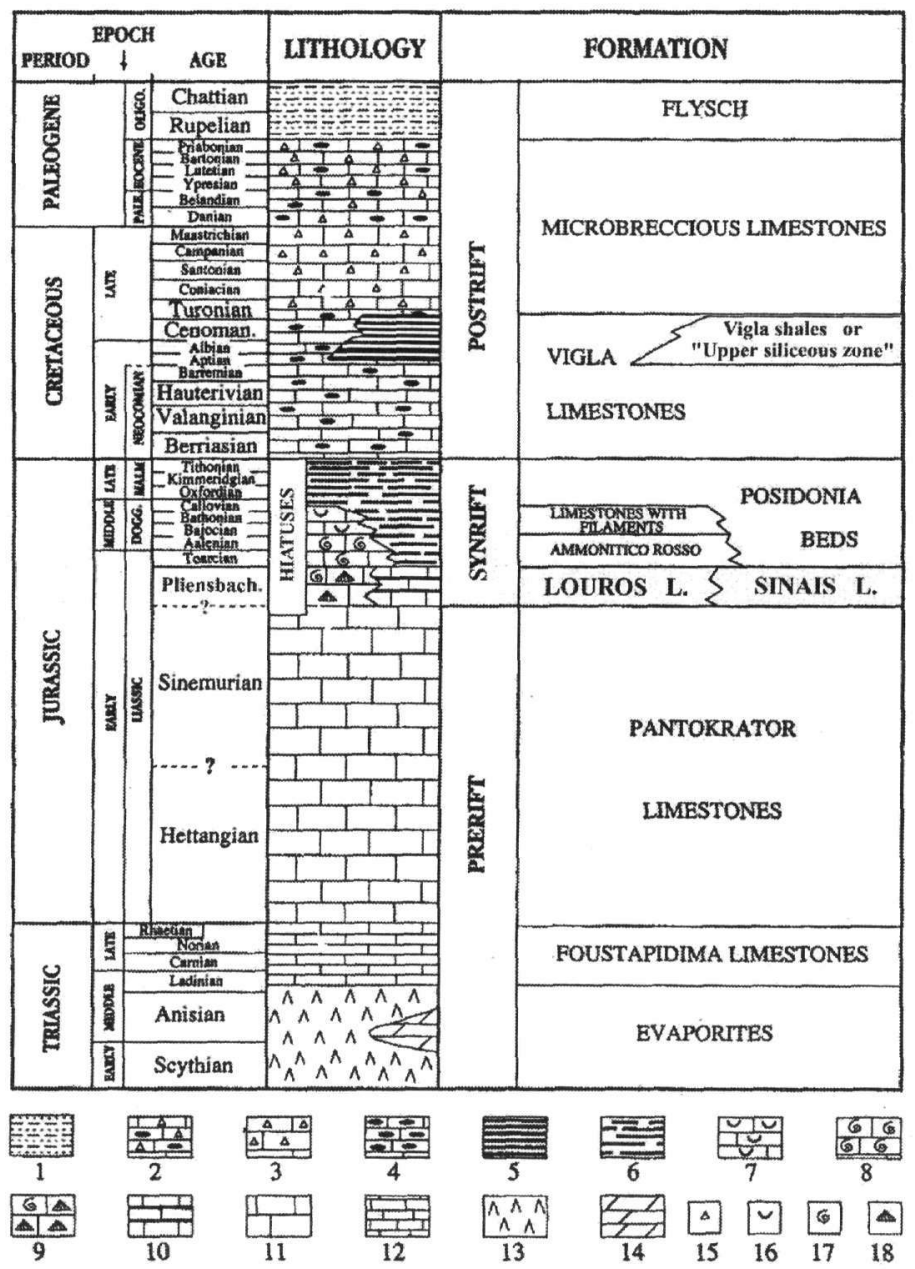

Figure 3. Representative sıratigraphic column of the Ionian zone (Karakitsios, 1995). 1. pelites and sandstones; 2. cherty limestone with clastic material; 3 . pelagic limestones with clastic material; 4. pelagic cherty limestones, 5 . cherty beds with green and red clay, sometimes shaly; 6 . pelagic limestones, marls, and siliceous argillites; 7 . pelagic limestones with pelagic lamellibranches; 8 . pelagic, red, nodular limestones with ammonites; 9. micritic limestones with small ammonites and brachiopods; 10. pelagic limestones; 11. platform limestones; 12. platy black limestones; 13. gypsum and salt; 14. dolomites; 15. breccia; 16. section of pelagic lamellibranches (filament); 17. ammonite; 18. brachiopod.

c) A postrift sequence is defined by an Early Barriasian breakup that is marked by an unconformity at the base of the Vigla Limestones (over the elevated part of the synrift half grabens). The postrift sequence (Vigla Limestones and overlying Alpine formations) largely obscures the synrift structures 
and, in some cases, directly overlies the Pantokrator Limestones prerift sequence. The permanence of differential subsidence during the deposition of the Vigla Limestones as shown by the strong variation in the thickness of this formation, is probably due to the continuation of halokinetic phenomena of the lonian zone evaporitic base. This paleogeographic configuration continued with minor off- and on-lap movements along basin margins until the late Eocene, when orogenic movements and flysch sedimentation began.

The main orogenic movements took place at the end of the Burdigalian (IGRS-IFP, 1966). The Ionian basin evolution constitutes a good example of inversion tectonics of a basin with evaporitic base (Karakitsios 1995).

\section{FACIES ANALYSIS}

Most specimens are represented by layered halite crystals appearing to be contemporaneously grown from a brine surface. Halite layers are considered being formed by superposition of crusts. The layers are composed of vertically elongate crystals, due to an upward competitive growth. Crystals are characterized by compromise curved boundaries, forming a puzzle texture (Fig. 4). Such a fabric is unlikely to develop by displacement of host sediment. Halite crystals contain abundant fluid (brine) inclusions concentrated in layers parallel to cube faces (100), so that zoning appears as chevron, givin, birth to chevron-type halite crystals. Cavities are created by dissolution of preexisted halite, due to under-saturated brines. These cavities have been filled by clear halite. In some cases halite crystals seem to have undergone fracture and redeposition.

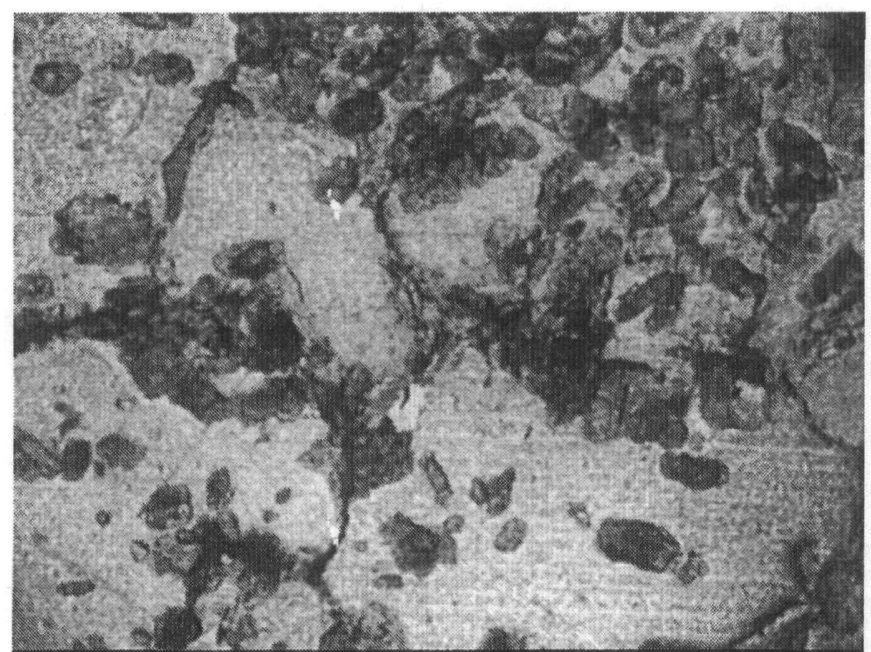

Figure 4. Halite crystals characterized by compromise curved boundaries, forming a puzzle texture. Brownish dolomite crystals occur along halite grain boundaries. Parallel nicols, $1.6 \mathrm{X}$.

Anhydrite always accompanies the halite crystals occurring as dispersed euhedral to subhedral crystals or as nodules in the form of spherical to ellipsoidal masses ( $1-5 \mathrm{~mm}$ in diameter). Nodules are characterized by mosaic of variable-sized anhedral crystals (Fig. 5), partially or entirely, replaced by dolo-microsparite. Gypsum has been not detected. 


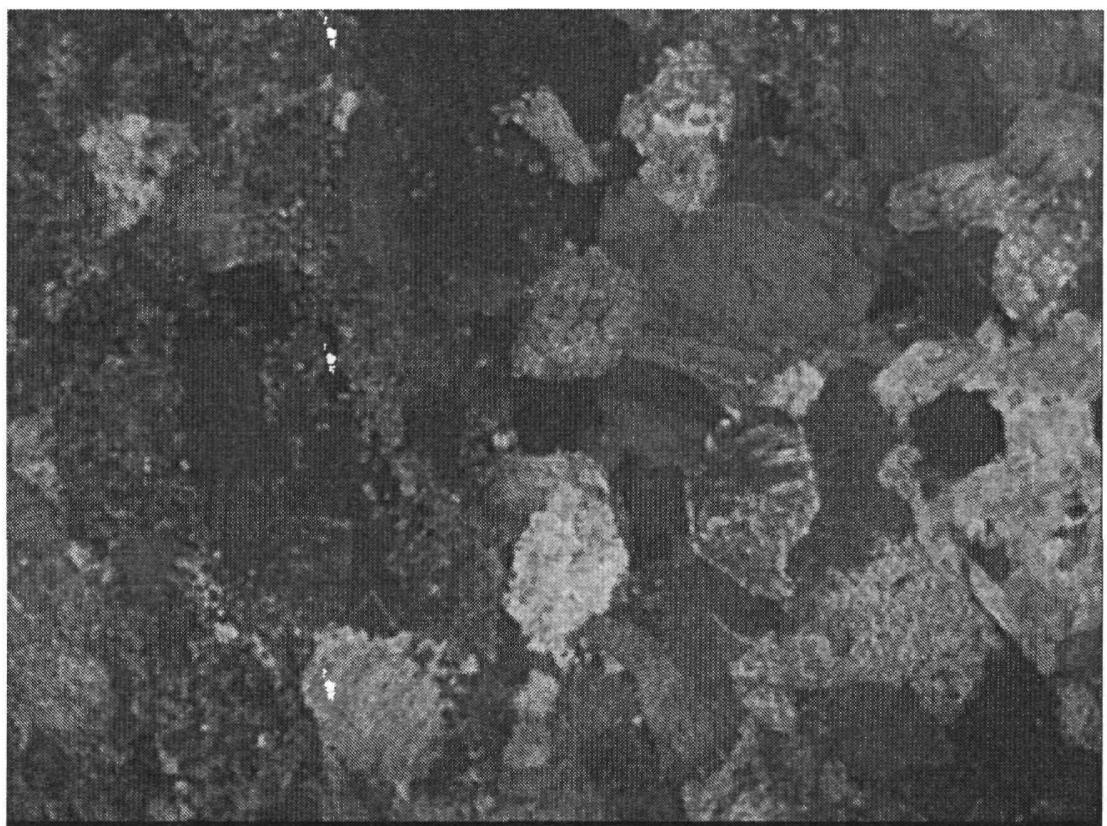

Figure 5. Mosaic consisted of euhedral to subhedral anhydrite crystals. Crossed nicols, 1.6X.

Along halite grain boundaries or sutures, brownish dolomite crystals occur (averaging $30 \mu \mathrm{m}$ in size), either as non-zoned individual rhombs or clusters of crystals (Fig. 6).

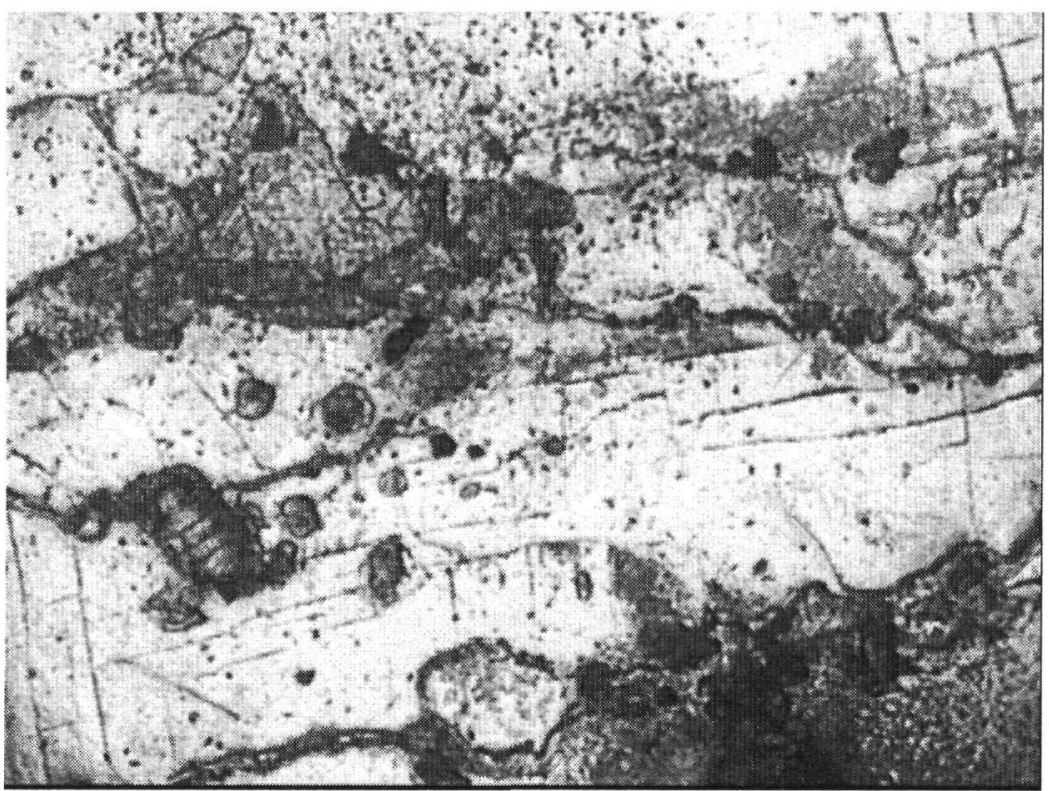

Figure 6. Chevron-like halite crystals developed in zones parallel to cube facies. Note a dolomite pseudomorph after rectangular anhydrite crystal. Parallel nicols, $1.6 \mathrm{X}$.

Dolomite grows on halite crystal surfaces as an early diagenetic mineral (El Tabakh et al. 2003). Some dolomite crystals are clearly derived by replacement of anhydrite laths or rectangular shaped anhydrite crystals (Fig. 7). Halite layers are rich in clay and carbonaceous material, which favors 
the development of redicing environment attested by the presence of euhedral to subhedral pyrite crystals.

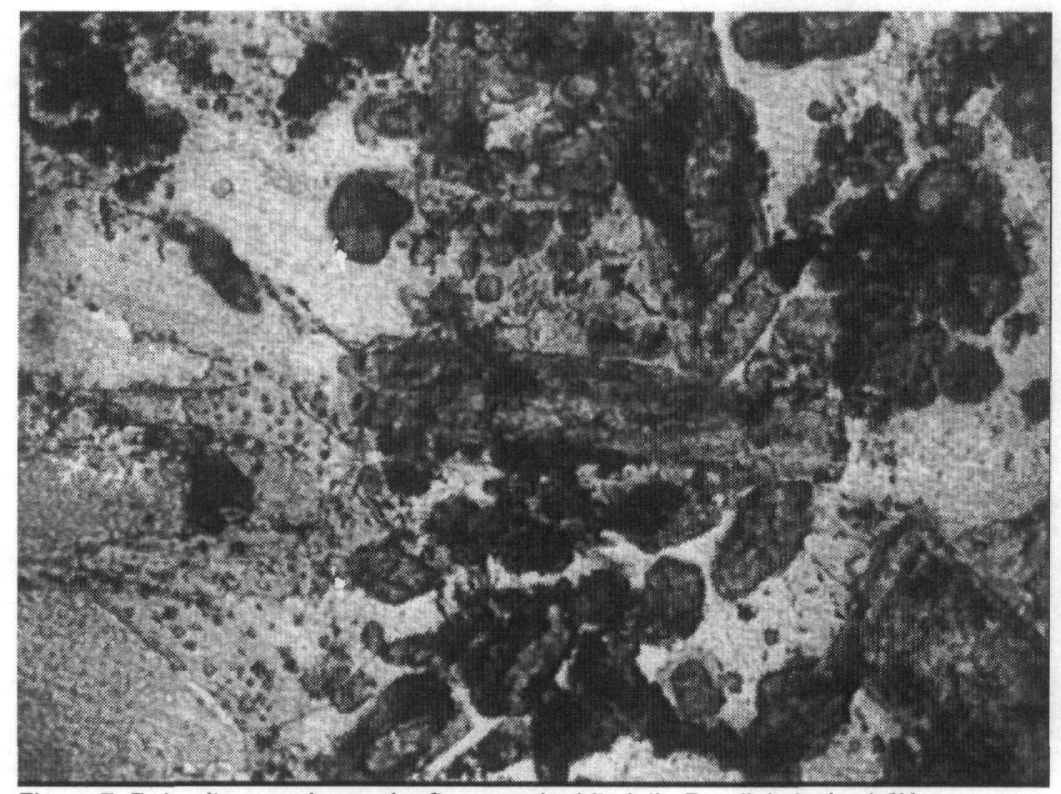

Figure 7. Dolomite pseudomorph after an anhydrite lath. Parallel nicols, 1.6X.

Anhydrite-bearing rocks occur in-between the halite layers. The matrix consists of subhedral to euhedral anhydrite crysials and / or nodules floating in a matrix of smaller-sized anhydrite crystals (Fig. 8). Anhydrite is characterized by high birefringence. Argillaceous matrix is enclosed between the crystals suggesting that both crystals and nodules have been clearly formed by displacement (Fig. 8)

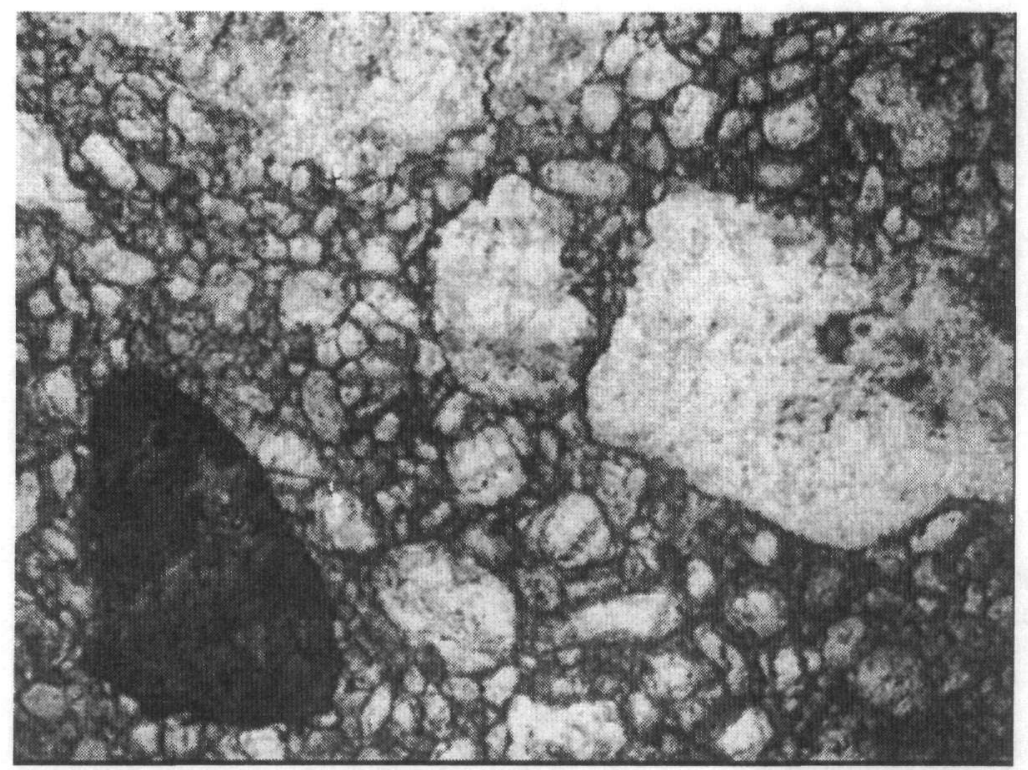

Figure 8. Development of anhydrite nodules and crystals in an argillaceous matrix. Parallel nicols, $1.6 \mathrm{X}$. 


\section{DEPOSITIONAL ENVIRONMENT}

Layered halite layers of the Ionian zone subsurface evaporites present remarkable similarities with halite crusts observed at the "seasonal layers" of the Middle Devonian Prairie Evaporite Formation of Saskatchevan (Wardlaw \& Schwerdtner 1966), and at Recent salt pans (Shearman 1970). In those cases, halite crusts are considered to be formed either by growth on the brine surface or by upward and lateral growth of floor-nucleated crystals, possibly recording annual precipitation. Inclusion-rich zones of halite crystals are formed when brines are over-saturated and consequently growth is rapid. On the contrary, reduced brine concentrations allow inclusion-free halite crystals deposition. Brine reconcentration can only occur by subsequent brine evaporation. Such a process can be achieved only in brines of small volume. Thus the alternation of inclusion-rich and inclusion-poor layers in halite is an indicator of shallow water precipitation.

On the other hand, the anhydrite nodules show clear indices of having been formed by displacement. Thus, the close association of layered halite with nodular anhydrite cannot exclude the possibility of halite development, in an emergent environment by displacement from capillary brines (Shearman 1966; Holliday 1967). Halite displacement has been recorded in the Dead Sea floor. Indication, that halite grew within host sediments by displacement, constitutes the zonal arrangement of the inclusions.

On shallow stable shelves with arid climates and low aeolian sand influx, the seaward progradation of subtidal and inte.tidal facies, generates broad coastal flats (or sabkhas) that lie just above high tide level and extend between the offshore water body (commonly with coastal lagoons) and regions of arid continental sedimentation. This environment is the consequence of both depositional and diagenetic processes. The most important of the diagenetic processes is the displacive growth of early diagenetic calcium sulphate or halite. Modern cratonic areas, such as the Arabian coasts of Persian Gulf and the coasts of Australia and North Africa, provide the most favorable settings for Recent sabkhas.

Halite deposits may become consolidated early in their history by crystallization and recrystallization processes. Garrett (1970), concluded that in shallow water deposits, much of the salt deposited in the evenirig redissolves during the day and subsequently recrystallizes, tending to consolidate the deposit.

Taking into consideration all the above data and since the studied halite crystals show evidence of mineral replacement and displacement, an analogous mechanism with that described by Shearman (1970) is suggested: accumulation from a standing body of brine and subsequent textural modification in the groundwater zone. In that case, the achievement of great thickness of the Ionian zone evaporites would require excessively high rates of relative subsidence.

Although, Ionian subsurface evaporites have undergone the above-mentioned diagenetic processes, they still retain their primary textural characteristics. Real brecciation has not been detected in subsurface, except oi an in-situ pseudo-brecciation, attributed to desiccation in subaerial environment. This observation clearly shows that the outcropping evaporite solution-collapse breccias (Pomoni-Papaioannou 1980; Karakitsios \& Pomoni-Papaioannou 1998) were formed in the realm of meteoric zone, after the Ionian zone orogenesis.

\section{DISCUSSION}

In a previous work (Karakitsios \& Pomoni-Papaioannou 1998), based on outcropping material, it was shown that the Triassic subsurface evaporites appear on the surface as evaporite dissolutioncollapse breccias. These observations had verified different stages of brecciation, starting from early diagenesis to post-orogenic "carneulisation"(formation of rauhwackes), without knowing the participation degree of each stage. The present work, carried out on subsurface evaporites, showed no real brecciation, except of a minor in-situ pseudo-brecciation. Consequently, the outcropping evaporite solution-collapse breccias were formed mainly in the realm of meteoric zone, after the Ionian zone orogenesis. This is in accordance with: a) the halokinesis that took place from Early Jurassic (the synrift sequence indicates that deposition was controlled both by structures formed during the extensional tectonic phase, related to the opening of the Neotethys Ocean, and the halokinesis of the Ionian zone evaporitic base) and b) the diapirism and inversion tectonics of the lonian basin during orogenesis (Karakitsios 1992; Karakitsios 1995). 


\section{CONCLUSIONS}

- Halite crystals of the lonian evaporites present remarkable similarities with the "seasonal layers" of Recent halite formations (sabkha type).

- Chevron-type halite supports accumulation beneath a body of brine, possibly recording annual precipitation cycles. However, its close association with nodular anhydrite cannot exclude the possibility of halite development, in a shallow-water or emergent environment by displacement from capillary brines. In that case, the great thickness of the lonian zone evaporites would require excessively high rates of relative subsidence. Nevertheless, since the studied halite crystals show evidence of mineral replacements and displacement, we suggest a mechanism which includes accumulation from a stancling body of brine and subsequent textural modification in the groundwater zone. Although, Ionian subsurface evaporites have undergone the above-mentioned diagenetical processes, they still retain their primary textural characteristics. Real brecciation has not been detected in subsurface, except of an in-situ pseudo-brecciation, attributed to desiccation, in subaerial environment. This observation clearly shows that the outcropping evaporite solution-collapse breccias were formed in the realm of meteoric zone, after the lonian zone orogenesis.

\section{REFERENCES}

BP 1971. The geological r€ jults of petroleum exploration in western Greece. Inst. Geol. Subs. Res., 10, 1-73.

Carissimo L., Agostino O. d', Loddo C. \& Pieri M. 1963. Petroleum Exploration by AGIP Mineraria and new geoIogical information in central and southern Italy from the Abruzzi to the Taranto gulf. VI Congres Mondial du Petrole, Frankfurt-am-Main, sect. I, (27).

Ciarapica G., Cirilli S., Passeri L., Trincianti E. \& Zaninetti L. 1987. «Anidriti di Burano» et «formation du Monte Cetona» (nouvelle formation), biostratigraphie de deux séries-types du Trias supérieur dans l' Apennin septentrional. Revue Paléobiologie, 6, (2), 341-409.

El Tabakh M., Utha-Aroon C., Warren J.K. \& Screiber B.C. 2003. Origin of dolomites in the Cretaceous Maha Sarakham evaporites of the Khorat Plateau, northern Thailand. Sed. Geol., 3-4, 235-252.

Garrett, D.E. 1970. The chemistry and origin of potash salts. In: Rau, J.L. and Dellwig, L.F., (eds), 3rd Symp. Salt. Northern Ohio Ge.)l. Soc, 1, 211-222.

Holliday D.W. 1967. Contribution to discussion of reference Shearman (1966). Trans. Inst. Min. Metall. (Sect. B: Appl. Earth sci. ), 76, B179-180.

IGRS-IFP 1966. Etude géologique de l'Epire (Grèce nord-occidentale). Paris, Ed. Technip, 1-306.

Karakitsios V. 1992. Ouverture et inversion tectonique du bassin ionien (Epire, Grèce). Ann. Geol. Pays Hell. $35,185-318$.

Karakitsios V. 1995. The Influence of Preexisting Structure and Halokinesis on Organic Matter Preservation and Thrust System Evolution in the Ionian Basin, Northwestern Greece. AAPG Bulletin 79, 960-980.

Karakitsios V. 2003. Evolution and Petroleum Potential of the Ionian Basin (Northwest Greece). International Conference \& Exhibition, AAPG, p 47.

Karakitsios V. \& Pomoni-Papaioannou F. 1998. Sedimentological study of the Triassic solution-collapse breccias of the Ionian zone (NW Greece). Carbonates \& Evaporites, 13( 2), 207-218.

Pomoni-Papaioannou F. 1980. Genesis-Diagenesis of Triassic Breccia and nodular Gypsum of Epirus. Miner. \& Petrogr. Research, Inst. Geol. \& Miner. Exploration, 30p.

Pomoni-Papaioannou F. 1983. Studiul Petrographic si Sedimentologic al Evaporitelor Triasice din Regiunea Epir. Teza de Doctorat, Universitatea Bucuresti, 190p., (unpublished).

Pomoni-Papaioannou F. 1985. The sedimentology and depositional environment of the Triassic dolomitegypsum facies of western Greece. $6^{\text {th }}$ Eur. Reg. Meet. Int. Ass. Sed., 367-368.

Shearman D.J. 1966. Origin of marine evaporites by diagenesis. Trans. Inst. Min. Metall. (Sect. B: Appl. Earth sci., 75, B208-215).

Shearman D.J. 1970. Recent halite rock, Baja California, Mexico. Trans Inst. Min. Metall., 79, $155-162$.

Wardlaw N.C. \& Schwerdtner W.M. 1966. Halite-anhydrite seasonal layers in Middle Devonian Prairie Evaporite Formation, Saskatchevan, Canada. Bull. Geol. Soc. Am., 77, 331-342. 